\title{
The marketing value creation in the waste management sector - multi-conceptual business model
}

\author{
Izabela Barbara Sztangret ${ }^{1 *}$ \\ ${ }^{1}$ University of Economics in Katowice, Department of Entrepreneurship; 1 Maja 50, 40-287 \\ Katowice, Poland
}

\begin{abstract}
The concept of marketing value occurred interesting due to a result of the process of transformation of traditional business relationships into specific type of cooperation of enterprises to create multivalued for demanding customers. It also concerns studied companies of the sector of waste collection and recycling, as well as their partners and customers. In the studied case, marketing value is created by enterprises, their cooperants and customers for the purpose of further satisfaction of target market need, in at least three-spherical business model. This model often has multiconcept, or holistic nature while combining relationship marketing, supply marketing, integral, internal, systemic, strategic and social marketing. Companies representing the sector of waste management apply smart technological solutions which result in interactive formation of market value. Smart ways of creation of marketing value, in the sector of waste management enterprises in the environment of IT solutions is the goal of this paper. The main research methods used are case studies.
\end{abstract}

Key words: business model, marketing value, waste management, waste selection

\section{Introduction}

The concept of marketing value occurred interesting due to a result of the process of transformation of traditional business relationships into specific type of cooperation of enterprises to create multivalued for demanding customers. It also concerns studied companies of the sector of waste collection and recycling, as well as their partners and customers. Peculiar character of cooperation is associated with the fact of approaching information as a resource constituting relationship in the network of enterprises and their customers, which can be successfully implemented in IT environment. Interactive contact and involvement of the stream suppliers and customers of secondary market form the operational sub-area of the concept of creation of marketing value, in studied sector, in subjective approach. This is the features of creation marketing value by integral marketing.

\footnotetext{
* Corresponding author: izabela.sztangret@ue.katowice.pl
} 
Technological tools enable smart management of communal waste through effective division into stream fractions, which consequently allows for separation of the material for recycling and reuse, management of the fraction obtained from mechanical-biological waste treatment, and first minimising the amount of non-productively stored waste. Knowledge about chemical composition of packaging getting into the waste stream tightens the process of precise selection. Organisational knowledge and competencies as well as skilful application of new technologies in the processes of selection and recycling of communal waste constitute the operational sub-area of creation of marketing value in interorganisational level, in process approach. It occurs as an extra-eco-marketing value and the symptom of strategy marketing value.

Commercial use of information automatically registered by separator scanners of particular fractions of communal waste is another operational sub-area of creation marketing value, in this case. Information included in the barcode is important in identification and registering a particular type of product. Thereby it has marketing value, useful in market research in functional approach to management in a company.

In the studied case, marketing value (valuable relations, eco-strategy value, marketing information) is created by enterprises, their cooperants and customers for the purpose of further satisfaction of target market need, in at least three-spherical business model. This model often has multi-concept, or holistic nature while combining relationship marketing, supply marketing, integral, internal, systemic, strategic and social marketing. Companies representing the sector of waste management apply smart technological solutions which result in interactive formation of market value.

Therefore, smart ways of creation of marketing value, in the sector of waste management enterprises in the environment of IT solutions, raise interest. Their identification and analysis is the goal of the paper ${ }^{2}$. This will be implemented through in-depth case study analysis.

\section{Research methods}

Regional Municipal Waste Treatment Facilities are, for the needs of this paper, the subject of the research. These entities are described in the Law on waste of 14th December 2012 and the Directive 2002/83/EC that determines the minimum requirements for establishment of such an entity. The documents also describe hierarchical method of waste management through:

1. prevention of waste generation,

2. preparation of its reuse,

3. recycling,

4. other processes of recovery,

\footnotetext{
${ }^{2}$ This topic seems to be quite now. We haven't got comprehensive studies on this topic in the literature. This knowledge is on the first stage of its development. But it is very endurable, because we need revolution in recycling: "This means we do not recycle from material to material but from material to elements and then back to completely different materials (with new value...). This way we could take composite ingredients, break them apart, and recycle everything, not just the organic or inorganic material like we do today", by Jutta Laine-Ylijoki, senior scientist at VTT. "Extracting valuable materials from side streams, such as oil, paint, or glue, is our main concern right now. In many cases, the actual process of fractioning these streams is not the problem, increasing the production to an industrial scale is (...). Another challenge for L\&T involves creating completely new products or materials from waste. Steel will be always recycled as steel, but plastic might turn into something completely different in its second life, by Mikko Paasikivi, business manager at L\&T [1].
} 
5. disposal.

The law provides the possibility to divide voivodeships, in voivodeship plans of waste management (VPWM) into regions, if they comply with the minimum requirements as determined in clause 35 section 5 of the law. It establishes that the region of municipal waste management constitutes an area of neighbouring communes that comprise in total at least 150 thousand inhabitants and is operated by facilities referred to in section 6 . The area of a commune of 500 thousand inhabitants can also be the region of municipal waste management. New regulations included in the amendment to the law on waste of 22nd January 2015 define a regional facility for municipal waste processing as the waste management plant of the capacity sufficient to collect and process waste from the area inhabited by at least 120 thousand inhabitants. Also, it must comply with the requirements of the best available technology referred to in clause 207 of the law of 27th April 2001 Environmental protection law, or technology referred to in clause 143 of this law, including those applying new available technologies of waste processing or ensuring that:

1) mechanical and biological treatment of mixed municipal waste and separation from mixed municipal waste the fractions that are suitable for recovery in whole or in part, or,

2) processing of separately collected green waste and other bio-waste, and producing from them a product of fertilising qualities, or substances supporting plant cultivation that comply with requirements as determined in separate regulations, or other material after the process of composting or fermentation admitted for recovery in the R 10 recovery process that meets the requirements determined in regulations issued on the basis of clause 30 section 4, or,

3) landfilling of waste generated in the process of mechanical and biological treatment of mixed municipal waste and remains from segregation of municipal waste of the capacity that allows for reception of waste for the period of at least 15 years, in the amount not smaller than generated in the facility for mechanical and biological treatment of mixed municipal waste [2]. Furthermore, the region of municipal waste management may comprise neighbouring communes of various voivodeships if it is provided for by voivodeship waste management plans of these voivodeships [3]. Another important provision of the quoted law concerns introduction of the notion of transregional facility which can be an incineration plant for municipal waste with the capacity sufficient for reception and treatment of mixed municipal waste collected from the area inhabited by at least 500 thousand residents, and that meets the requirements of the best available technology called "transregional municipal waste incineration plants".

Table 1. Basic information about conducted research

\begin{tabular}{|c|c|}
\hline Specification & Characteristic features \\
\hline Research technique & $\begin{array}{c}\text { Critical analysis of the literature and trade magazines, analysis } \\
\text { of webpages, analysis of sponsored interviews, direct interviews }\end{array}$ \\
\hline Sample selection & Targeted selection of typical units \\
\hline Sample size & $\begin{array}{c}\text { Leader of waste management sector in region IV, by the } \\
\text { criterion of facility machinery } \\
20 \text { representatives of RIPOK [regional municipal waste } \\
\text { treatment facility] in Poland }\end{array}$ \\
\cline { 2 - 2 } & Over 10 trade webpages related to waste management sector \\
\hline Geographical range & Regional range \\
\hline Time range & $2014-2019$ \\
\hline
\end{tabular}

Source: Authors. 
MASTER Odpady i Energia Sp. z o.o. enterprise [MASTER Waste and Energy limited liability company], being one of 3 similar facilities constructed in Poland that have the latest plant ensuring mechanical and biological treatment of mixed municipal waste and separation of fractions, from mixed municipal waste, that are recyclable in whole or in part, of the capacity of $120,000 \mathrm{Mg} /$ year. The plant, together with the landfill constitutes an integral part of communal waste management system in Region IV.

The paper applies the methods of conceptual research, and qualitative empirical research (case study) ${ }^{3}$. Analysis of the literature of the subject and research based on secondary and primary sources was performed.

For the needs of the entities that have the status of RIPOK [Regional Municipal Waste Treatment Facility] by the criterion of indication by a leader and position according to secondary sources of the sector were selected for the analysis of expanded case study ${ }^{4}$.

\section{Waste selection and inter-processing as a way of integral marketing}

The aforementioned directive 2008/98 / EC of the European Parliament and of the Council of 19 November 2008 on waste, and the one repealing certain directives (hereafter: the Framework Directive), focus on the prevention of negative impacts of waste generation, its management and protection of natural resources. It brings a new approach to waste management and also changes the way people think about waste, while recognizing it as a valuable resource. The directive emphasizes the definition of key concepts such as: recovery, disposal and recycling $(3 \mathrm{R})^{5}$. The Framework Directive stresses the need to establish a recovery and waste disposal facility using the best available technology (BAT-Best Alternative Technology, BREF-Reference Document on Best Available Techniques for the Waste Treatment Industries) [4], which represents appropriate use of diverse and complementary technological solutions and waste processing processes. This means that waste management system can be based on various technologies and technological processes that allow for the management of collected municipal waste, recycling, thermal

\footnotetext{
${ }^{3}$ Application of the method seems justified because:

$1 /$ research concerns contemporary, dynamic phenomena and knowledge about these phenomena that is created;

$2 /$ they concern research of actual contexts of these phenomena at rather large ambiguity of borders between their contexts and the very phenomena;

$3 /$ the subject of research is too complicated to explain the cause and effect relationships by means of the survey method or experiment $[5,6]$.

${ }^{4}$ Sample selection was performed on the basis of leader's indication and on the basis of indications in final report of III stage expert opinion aiming at performance of waste examination in 20 waste mechanical and biological treatment plants financed from resources of the project no POPT.03.01.0000-375/13-00, „Wsparcie na działania sieci organów środowiskowych i instytucji zarządzających funduszami unijnymi" "Partnerstwo: Środowisko dla Rozwoju"[ ["Support for activities of the environmental networks and institutions managing EU funds." "Partnership: environment for development"] in 2014 from Resources of 2014 Technical Assistance Operational Programme 20072013 within Priority III - Support for execution of structural funds operation; Action 3.1. „Functioning of institutions involved in NSRF”. Executor: Consortium: Uniwersytet Zielonogórski i Zakład Utylizacji Odpadów Spółka z o.o., [University of Zielona Góra and Waste Disposal Facility limited liability company] [7].

${ }^{5}$ The concept described more broadly in the author's publications: Zrównoważony rozwój przez zarządzanie wiedzą w eko-systemie interesariuszy, na przykładzie przedsiębiorstwa usług komunalnych $[8,9]$.
} 
transformation or energy recovery. Other forms of waste recovery that require pre-treatment (separation of individual fractions) is acceptable as this allows for further neutralisation of the waste by processing. The scheme of the municipal waste treatment in studied RIPOKs [Regional Municipal Waste Treatment Facilities] includes most frequently four main components, described below:

1) Thermal conversion of waste involves oxidation of waste (including incineration and gasification) or decomposition of waste (including pyrolysis). These processes can be conducted in incineration plants for hazardous waste and in municipal waste incineration plants, and in the case of non-hazardous waste, in installations other than waste incineration plants or in other facilities in the way compliant with specific provisions.

2) Mechanical-biological waste processing consists of mechanical processing of waste and biological waste treatment combined into one integrated technological process of mixed municipal waste processing for the purpose of preparing them for recovery, including recycling, energy recovery, thermal conversion or storage. The mechanical processes include, among others, grinding, sifting, sorting as well as segregation of ferrous and non-ferrous metals. Once these processes have been performed, organic fraction is left, and it undergoes biological aerobic or anaerobic stabilization. Biological processing of waste in aerobic conditions is conducted in accordance with strictly defined requirements. Waste separated as a fraction $0-80 \mathrm{~mm}$ is processed with a transfer of waste for a total period of 8 to 12 weeks, including at least 2 weeks' process in a closed reactor or in a hall with active aeration, when impurified process air is prevented from being released into the atmosphere until AT4 value below $20 \mathrm{mg} \mathrm{O} / \mathrm{g}$ of dry matter is obtained (perceived as breathing activity - a parameter expressing the oxygen requirement for a sample of waste for 4 days). In biological waste treatment processes in anaerobic conditions, the aforementioned waste is subject to stabilization in a twostage process:

a) In the first stage of mesophilic fermentation, for at least 20 days, or thermophilic fermentation, for at least 12 days, in a second oxygen stabilization stage in a closed reactor or in a hall with active aeration, with a protection preventing release of impurified process air into the atmosphere for at least the period of 2 weeks' time;

b) in the second stage of aerobic stabilization, stabilization conducted in openair prisms, aerated by waste moving once a week at least, for the period of at least 3 weeks is admissible.

3) Processing of selectively collected green waste and other bio-waste, i.e. composting, consists in the processing of waste by means of natural reactions of decomposition of organic substances by microorganisms. Processing takes place under controlled conditions, in the presence of oxygen and in appropriate temperature and humidity levels, and with the participation of microorganisms. The purpose of composting is to obtain organic fertilizer, at a considerable reduction in the volume of deposited waste (even by half), and a neutral chemical and biological impact of the obtained "product" on the environment.

4) Storage is a disposal method applied for waste which, for technological or economic reasons, has failed to be recovered or disposed with the use of other methods. Landfill waste is stored in a selective way according to the types specified in the landfill operating instructions.

The most modern methods for reduction of the amount of waste on stock include depolymerisation, bio-drying, hydro-mechanical segregation and autoclaving.

5) Depolymerisation is the process of plastic waste processing that takes place through the decomposition of hydrocarbon chains under the influence of temperature, lack of air, and with the use of a catalyst. As a result, a product of new properties is obtained. The 
liquid fuel component, synthetic paraffin oil which is a component of diesel oil and a substitute for heating oil, is the final product of the catalytic depolymerisation process.

6) Bio-drying takes place in boxes with intensive aeration. Waste is transported in containers to the place, where piles are built and then covered with semi-permeable geomembrane. The process of intensive stabilization in aerobic conditions takes place in the piles. After about 21 days of processing, the processed waste is sorted, and it can be sent to the production line for production of alternative fuels, or transferred as the socalled. Pre-RDF28 used in energy-intensive industries such as cement plants.

7) Hydromechanical separation involves the separation of the mixed stream of waste by means of hydro-separation. Plastics (light fraction) float on water, the organic fraction moves in the water, while heavy fractions such as metals and minerals fall to the bottom. This method allows for recovery of about $70-90 \%$ of materials for further recycling. Organic fraction undergoes the process of fermentation and then is used to produce fertilizers.

8) Autoclaving involves mechanical and thermal treatment of waste. During the process, odours and pathogens are eliminated. This technology applies three physical factors, automatically controlled on the basis of waste morphology: temperature, pressure and time. Sterilized waste is subject to mechanical sorting.

Sterile organic fractions and pure nonorganic fractions that can be recycled are released from the stream of mixed municipal waste [10].

Investigated Complex Waste Management Plant in Tychy, managed by Master Odpady $i$ Energia Sp. z o.o. company focuses on full eco-innovation of waste management solutions. At the plant in Tychy, practically all possible solutions for efficient sorting of waste are practically applied. The main element that distinguishes the plant is the use of $8 x$ optical separators, $3 x$ separators of ferrous metals, a non-ferrous metal separators and $2 D / 3 D$ ballistic separator of hard parts for biological fraction. Thanks to smart technological solutions they can separate the individual raw materials from the waste stream with the effectiveness of over $80 \%$ on the basis of recognition of physical and chemical qualities of the waste.

Waste selection by suppliers of the stream of waste, smart inter-processing of interorganizational knowledge, skills and technology, relations based on information/knowledge diffusion between suppliers, companies of municipal waste sector and aims of secondary market creates the area of creation integral marketing value.

\section{Informative value of the waste}

The information contained in, or on waste, that constitutes the stream, and is obtained by an enterprise of studied sector can be used effectively to streamline the selection process, on the level of segregation of raw material to be processed or sold. Furthermore, they can provide information about buying and consumption behaviours of creators/suppliers of waste stream.

According to the Ordinance of the Minister of the Environment on packaging design patterns of 23 April 2004, the marking of the packaging of goods is determined by their chemical composition. The packages which have a significant environmental impact have been distinguished. This allows for identification, with the use of optoelectronic and laser separators, of waste streams for example for pyrolysis, self-depolymerisation or sales on the secondary market. The most important markings are shown in Table 2. 
Table 2. Marking of packaging by chemical composition

\begin{tabular}{c} 
Composition \\
crockery \\
plaminium, found in for example cans and disposable \\
plastic found for example in \\
appliances \\
Bottles, dishes, packages, and housings of household \\
$\begin{array}{c}\text { High density polyethylene - pehd, hdpe, used for example } \\
\text { for production of foils, packaging, garbage bags, sewage } \\
\text { pipes, rainwater tanks and garbage containers }\end{array}$ \\
\hline $\begin{array}{c}\text { Polyvinyl chloride - pve, contained for example in } \\
\text { syringes, liners and insulation of cables }\end{array}$ \\
\hline $\begin{array}{c}\text { Low density polyethylene - ldpe, peld, which is contained } \\
\text { in plastic bags }\end{array}$ \\
\hline $\begin{array}{c}\text { Polypropylene - pp, used for example in foam insulation, } \\
\text { floor coverings, toys, household appliances }\end{array}$ \\
\hline $\begin{array}{c}\text { Polystyrene - ps, contained for example in styrofoam, } \\
\text { fancy goods and toys }\end{array}$
\end{tabular}

Source: [3].

Waste Transfer Card (KPO) is another source of information and intra-organisational knowledge, also offering the possibility of its commercial use. This card is the evidence for appropriate disposal of waste by the entity / supplier of the stream, while omitting a natural person, at entitled recipients, according to the waste code as specified in the Code Catalogue [Regulation of the Minister of the Environment of 27 September 2001 on the waste catalogue]. The waste catalogue divides the waste according to the source of its formation in 20 groups as shown in table 3 . 
Table 3. Catalogue of waste by groups

\begin{tabular}{|c|c|}
\hline Waste type & Marking \\
\hline $\begin{array}{l}\text { Waste arising from the search, extraction, physical and chemical processing of ores and } \\
\text { other minerals }\end{array}$ & 01 \\
\hline $\begin{array}{l}\text { Agricultural, horticultural, hydroponic, fishery, forestry, hunting and food processing } \\
\text { waste }\end{array}$ & 02 \\
\hline $\begin{array}{c}\text { Waste from wood processing and from the manufacture of boards and furniture, } \\
\text { cellulose pulp, paper and cardboard }\end{array}$ & 03 \\
\hline Waste from the leather, fur and textile industries & 04 \\
\hline Waste from crude oil processing, natural gas purification and pyrolytic coal processing & 05 \\
\hline $\begin{array}{c}\text { Waste from the manufacture, preparation, marketing and use of nonorganic chemical } \\
\text { products }\end{array}$ & 06 \\
\hline $\begin{array}{c}\text { Waste from the production, preparation, marketing and use of products of the organic } \\
\text { chemistry industry }\end{array}$ & 07 \\
\hline $\begin{array}{l}\text { Waste from the manufacture, preparation, marketing and use of protective coatings } \\
\text { (paints, varnish, ceramic enamels), putty, adhesives, sealants and printing inks }\end{array}$ & 08 \\
\hline Waste from the photographic industry and services & 09 \\
\hline Waste from thermal processes & 10 \\
\hline $\begin{array}{l}\text { Waste from chemical treatment and coating of metals and other materials, and from non- } \\
\text { ferrous metal hydrometallurgical processes }\end{array}$ & 11 \\
\hline Waste from shaping and physical and mechanical processing of metals and plastics & 12 \\
\hline Waste oils and liquid fuel waste (excluding edible oils and groups 05,12 and 19) & 13 \\
\hline Wastes from organic solvents, coolants and propellants (excluding groups 07 and 08 ) & 14 \\
\hline $\begin{array}{c}\text { Packaging waste; sorbents, wiping cloths, filter materials and protective clothing not } \\
\text { included in other groups }\end{array}$ & 15 \\
\hline Waste not included in other groups & 16 \\
\hline $\begin{array}{l}\text { Waste from the construction, repair and dismantling of buildings and road infrastructure } \\
\text { (including soil and soil from contaminated sites) }\end{array}$ & 17 \\
\hline Medical and veterinary waste & 18 \\
\hline $\begin{array}{l}\text { Waste from installations and equipment for the management of waste, sewage treatment } \\
\text { plants and the treatment of drinking water and water for industrial purposes }\end{array}$ & 19 \\
\hline Municipal waste including selectively collected fractions & 20 \\
\hline
\end{tabular}

Source: [2].

The waste code defining the type of waste consists of six digits. Hazardous waste is indicated in the catalogue by the top index in the form of a "*" star.

\section{5 "Trash can content" as a aim of marketing research}

The results of the analysis of the information contained in the barcode label of municipal waste and so-called analysis of the contents of the trash can have a marketing value and can be the basis for the marketing decisions of the suppliers of a particular type of product on the market. Therefore, they may be the subject of knowledge commercialization in relationships between enterprises operating in waste management sector and companies or research agencies. The barcode is a graphical representation of information through a combination of dark and light elements, determined by the code symbols of the code structure. Graphics correspond to a sequence of numbers, each of which is the carrier of specific information. Two or three initial digits are the country of origin (the country code is 590), the next five digits are the manufacturer's code assigned by the Universal Copyright Convention (UCC). The next digit is the product code assigned by the manufacturers, and the control digit confirming the correctness of the scan. The digital representation of what the code contained 
in the code is intended to allow to manually enter the code, if the reader is unable to read the information. The code is an informational value when the electronic reader (laser, diode or camera) is automatically read by the reader, allowing the product to be identified.

On the other hand, the information from the analysis of "trash can content" (the socalled garbology analysis") [11] refers to household shopping and consumption habits, which can be the subject of comparative analysis in the category of the subject (residential and non-residential areas, including industrial areas). Geographic (international, regional, local), territorial unit (city, village), type of residential (single or multi-family buildings), or time, with the distinction of "special periods" (e.g. holidays, holidays period etc.). Analysis of the content of trash can may concern:

1) the structure of purchased and consumed goods in the household, by residents of a building, estate, district, companies of their groups, in a specific area;

2) eco-habits, manifested in purchasing behaviour and tendency to segregate waste;

3) quantity of consumed / consumed good of a category, in a given unit of time and the amount of single purchase expressed for example by the size of the package;

4) intensity of consumption, expressed as the time of filling the trash and the frequency of emptying;

5) social level of the household;

6) information about consumer habits concerning consumption of highly processed products or products / raw materials;

7) information about preferences regarding local, national or foreign product preferences;

8) the degree of waste of purchased products: food, household and TV appliances and electronics.

\section{Conclusions. Implications for Business Marketing Practice}

As shown by the results of research and analysis, the marketing value acquired in the competent, multi-faceted and multi-concept activities of waste sector entities, who establish systemic relationships with stream providers, aims of secondary markets, customers and research agencies in the process of direct and indirect relations (Figure 1). 


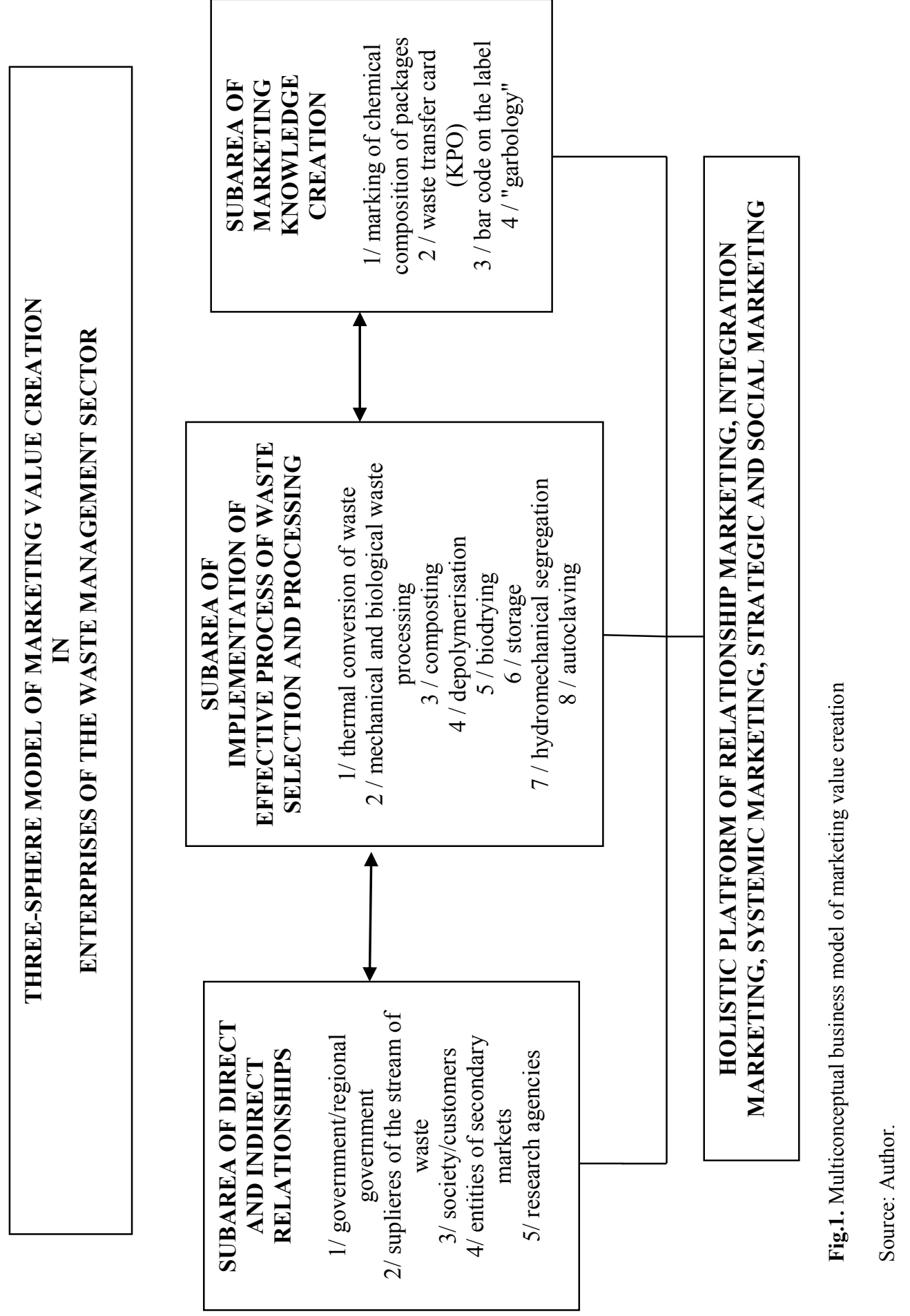


Wide range of activities of entities of waste management sector appreciates the holistic and multi-nature of model of creation of marketing value. These are the value of relations, value of wellness of society in long term perspective and social responsibility, commercial value of marketing information included in waste.

Knowledge, skills and eco-awareness are the linking elements in outside and inside relationships, but also the determinants of efficient logistics processes, including intraorganizational ones, in formulating the parameters of appropriate waste streams, desirable because of technological solutions used in the plant. In addition, information obtained based on the analysis of acquired waste starts to gain a new commercial dimension and opens a broad field of cooperation on functional basis of management, i.e. marketing research. It is not enough appreciated by entities of both sectors yet.

\section{References}

1. P. Pekkala, Creating New Value from Waste and Industrial Side Streams. Bioeconomy [online], Available at: https://makingoftomorrow.com/creating-new-value-wasteindustrial-side-streams/ (2017)

2. Ministry of the Environment, Environmental Protection Law, 27th April 2001 clause 143 (2001)

3. Ministry of the Environment, Reference document on Best Available Techniques for Industrial Waste Processing [online], Available at: http://ippc.mos.gov.pl (2006)

4. Ministry of the Environment Best Available Techniques for Industrial Waste Processing (2006)

5. Ch. Perry, Case Research in Marketing. The Marketing Review, (1), 303-323 (2001)

6. T. Żabińska, L. Żabiński, Zarządzanie marketingowe. Koncepcje marketingu a praktyki zarządzania [Marketing management. Marketing concepts and management practices]. Aspekty teoretyczne i badawcze, [Theoretical and research aspects], Publisher: AE Katowice, University of Economics in Katowice (2007)

7. „Wsparcie na działania sieci organów środowiskowych i instytucji zarządzających funduszami unijnymi" "Partnerstwo: Środowisko dla Rozwoju" ["Support for activities of the environmental networks and institutions managing EU funds." "Partnership: environment for development"] in 2014 from Resources of 2014 Technical Assistance Operational Programme 2007-2013 within Priority III - Support for execution of structural funds operation; Action 3.1. - „Functioning of institutions involved in NSRF”. Executor: Consortium: Uniwersytet Zielonogórski i Zakład Utylizacji Odpadów Spółka z o.o., University of Zielona Góra and Waste Disposal Facility limited liability company, Zielona Góra, (2015). Available at: www.ekspertyzambp.com.pl. (2016)

8. I. Sztangret, Zrównoważony rozwój przez zarządzanie wiedzą w eko-systemie interesariuszy, na przykładzie przedsiębiorstwa usług komunalnych [Sustainable development by knowledge management in the eco-stakeholder system, on the example of a utility company], Wydawnictwo Naukowe Uniwersytetu Szczecińskiego [Scientific Publishing House of the University of Szczecin], Studies and Research Papers of the WNEiZ US 43/2 (2016)

9. I. Sztangret, Intelligent knowledge management in the sector of waste disposal enterprises. III. International Scientific Conference - Winter session Industry 4.0 (2018) 
10. T. Styś, R. Foks, Rynek gospodarowania odpadami komunalnymi w Polsce. Perspektywa 2030 [Market for municipal waste management in Poland. Perspective 2030] (2014)

11. J. Baguchinsky, Adventures in Garbology: What Trash Can Tell Us [online], Available at: http://itech.fgcu.edu/\&/issues/vol2/issue2/garbology.htm (1999) 